\title{
Did accelerated filing requirements and SOX Section 404 affect the timeliness of 10-K filings?
}

\author{
Joost Impink • Martien Lubberink • Bart van Praag • \\ David Veenman
}

Published online: 16 October 2011

(C) The Author(s) 2011. This article is published with open access at Springerlink.com

\begin{abstract}
This paper examines the effect of Sarbanes-Oxley provisions on 10-K filing delays. We find that tightened filing deadlines for accelerated and large accelerated filers are not associated with changes in the incidence of late filing. While Section 404 compliance does not affect filing timeliness for firms with effective internal controls, we find that about half the firms disclosing internal control weaknesses are late filers. As a consequence, many Section 404 material weakness firms experience negative abnormal returns around late filing notifications before filing the 10-K. Lastly, we find that market reactions to late filing notifications are more negative when management provides no meaningful explanation for the delay, consistent with managers' incentives to withhold bad news.
\end{abstract}

J. Impink

Warrington College of Business Administration, University of Florida,

336 GER, PO Box 117166, Gainesville, FL 32611-7166, USA

e-mail: joost.impink@warrington.ufl.edu

M. Lubberink

Lancaster University Management School, Bailrigg, Lancaster LA1 4YX, UK

e-mail: m.lubberink@lancaster.ac.uk

M. Lubberink

DNB (The Netherlands Bank), Westeinde 1, 1017 ZN Amsterdam, The Netherlands

B. van Praag

Amsterdam Business School, University of Amsterdam, Plantage Muidergracht 12,

1018 TV Amsterdam, The Netherlands

e-mail: b.j.vanpraag@uva.nl

D. Veenman $(\bowtie)$

Erasmus School of Economics, Erasmus University Rotterdam, Burgemeester Oudlaan 50,

3062 PA Rotterdam, The Netherlands

e-mail: dveenman@ese.eur.nl 
Keywords Form 10-K - Rule 12b-25 - Accelerated filing · SOX Section 404 . Internal controls

JEL Classification $\mathrm{G} 14 \cdot \mathrm{G} 18 \cdot \mathrm{K} 22 \cdot \mathrm{M} 41$

\section{Introduction}

This paper examines the effect of Sarbanes-Oxley (SOX) provisions on the timeliness of 10-K filings. We first test whether the accelerated filing deadlines (Section 409) and internal control disclosure requirements (Section 404) of SOX affect firms' ability to file on time. Next, we examine whether investors draw inferences from management's explanations for filing delays on SEC Form 12b-25, particularly explanations related to SOX compliance and weaknesses in internal controls. These analyses are relevant to regulators, auditors, managers, and users of financial information, given that regulatory changes following SOX both reduced the 10-K filing deadline from 90 to 60 days after the fiscal year-end (SEC 2005a) and imposed additional tasks on managers and auditors. These additional tasks may impair firms' ability to meet the accelerated filing deadline (SEC 2002c; KPMG 2003; Durfee 2004; Ettredge et al. 2006; Krishnan and Yang 2009).

For a sample of 38,414 10-K filings for fiscal years ending between 1999 and 2006 , we find that 3,419 filings (9\%) are made after the due date; in $94 \%$ of these cases, firms comply with Rule $12 \mathrm{~b}-25$ to notify the SEC by filing a Form 12b-25, which grants a 15-day extension. For a reduced sample of 34,191 10-K filings by previously timely firms (that is, firms filing their $10-\mathrm{K}$ on time in the previous year) with available data for multivariate analyses, we find no evidence that the accelerated deadlines of 2003 (from 75 to 60 days for accelerated filers) and 2006 (from 75 to 60 days for large accelerated filers) are associated with an increased incidence of late filing. This result is inconsistent with claims that the increased effort imposed by SOX makes it more difficult for firms to comply with accelerated filing deadlines.

Focusing on the effect of Section 404 internal control disclosure requirements, we find increased late filing by previously timely accelerated filers during the period 2004 through 2006. This finding is consistent with the conjecture that Section 404 compliance results in less timely 10-K filings (Ettredge et al. 2006). However, when splitting the sample between firms with and without material internal control weaknesses, we find that the former drive the increased incidence of late filings. Thus, Section 404 appears most burdensome to those firms for which it is most warranted.

For a sample of 1,178 firms reporting material internal control weaknesses during 2004 through 2006, we find that 600 firms (50.9\%) file their 10-Ks late. While late filers should notify the SEC and provide an explanation for filing late on Form $12 \mathrm{~b}-25$, we show that an explanation triggers negative abnormal returns $(-1.35 \%)$ when it pertains to material internal control weaknesses. Additional tests show that market reactions to Form 12b-25 filings are more negative for firms subsequently disclosing material weaknesses in the $10-\mathrm{K}$ and that market reactions to $10-\mathrm{K}$ filings 
for material weakness firms are significantly less negative when preempted by a Form 12b-25. Section 404 material weaknesses thus trigger negative stock market reactions. Lastly, consistent with managers withholding bad news, not disclosing a meaningful explanation on Form $12 b-25$ is associated with negative market reactions to late filing notifications $(-1.44 \%)$.

This paper contributes to the literature on 10-K filing delays and Form 12b-25 filings (Alford et al. 1994; Griffin 2003; Bryant-Kutcher et al. 2007). We find that compliance with filing deadlines and Rule $12 \mathrm{~b}-25$ in the current regulatory regime is higher than previously documented by Alford et al. (1994) for the period 1978-1985. Next, we provide new evidence on the impact of the accelerated filing deadlines imposed by SOX and find no evidence that these deadlines are associated with an increased incidence of late filing. We further contribute by examining the market effects of two previously unexplored types of late filing explanations on Form 12b-25: SOX internal control related explanations and lack of a meaningful explanation (a form of nondisclosure).

We also contribute to research on the economic consequences of Section 404 internal control provisions including compliance with filing deadlines (Ettredge et al. 2006) and disclosure of weaknesses in internal controls (Ogneva et al. 2007; Beneish et al. 2008; Hammersley et al. 2008; Ashbaugh-Skaife et al. 2009). With regard to the former, we find that late filing increased around initial compliance with Section 404. (In 2003 and 2004, 7 and 14\% of firms are late, respectively.) This is in line with Ettredge et al. (2006), who find an increase in audit report lags for fiscal 2004. However, after controlling for other determinants of filing delays, we find that firms with material internal control weaknesses (of which about half are late filers) drive this result. Adding to the literature on the market impact of material weakness disclosures (Beneish et al. 2008; Hammersley et al. 2008), we show that given the requirement to explain the delay on Form 12b-25, Section 404 material weaknesses trigger negative abnormal returns around the filing of Form 12b-25, which occurs before the disclosure of the audit opinion in the $10-\mathrm{K}$.

The paper proceeds as follows. Section 2 discusses the institutional setting, prior literature, and hypotheses. Section 3 presents the data and a descriptive analysis of late filings and Rule 12b-25 compliance. Section 4 describes the empirical model, Sect. 5 presents results, and Sect. 6 concludes.

\section{Background and hypotheses}

\subsection{Institutional setting and regulatory changes}

For registered firms in the US, the SEC prescribes the due dates for quarterly and annual report filings. For fiscal years ending before 15 December 2003, the statutory filing deadline was 90 days after the year-end for annual financial statements (10-K) and 45 days after the quarter-end for quarterly financial statements (10-Q). Following Section 409 of SOX, the SEC shortened these filing periods. "Accelerated 
filers" ${ }^{1}$ with fiscal years ending on or after 15 December 2003, were required to file annual (quarterly) reports within 75 (40) days after the end of the period. "Large accelerated filers" (filers with a public float of more than $\$ 700$ million) with fiscal years ending on or after December 15, 2006, face a 60-day annual report-filing deadline. The deadline for quarterly reports is 40 days for both accelerated and large accelerated filers.

When a registrant cannot file the report "without unreasonable effort or expense," Rule 12b-25 of the Exchange Act requires the firm to notify the SEC by filing a Form 12b-25 no later than one business day after the statutory due date and explain the reason for the delay. The filing automatically grants a 15 (5) day extension to submit Form 10-K (10-Q). Failure to file on time can lead to trading suspension (Schwartz and Soo 1996a) or delisting (Alford et al. 1994). Stock exchanges apply their own rules governing late filings.

Besides imposing the accelerated filing deadlines, the Sarbanes-Oxley Act also imposed costly internal control disclosure requirements on firms through Section 404 (DeFond and Francis 2005; Hansen et al. 2009). This section requires a management- and auditor-attested report on the effectiveness of internal controls over financial reporting in Form 10-K. Initially, only accelerated filers were required to comply with Section 404 for years ending on or after 15 November $2004 .^{2}$

Empirical evidence on the costs and benefits of SOX compliance is mixed. Early evidence by Jain and Rezaee (2006) of positive (negative) market reactions to legislative events that increased (decreased) the likelihood of SOX enactment suggests that investors expected the benefits to outweigh the costs of compliance. In contrast, Zhang (2007) finds significantly negative abnormal returns to key SOX events, suggesting expected net costs of compliance and positive abnormal returns for smaller firms at the deferral of Section 404 compliance. Gao et al. (2009) show that small firms attempt to stay small to be exempted from Section 404. Engel et al. (2007) document an increase in going private transactions, suggesting expected reporting costs outweigh the expected benefits for certain firms. Observing that SOX and Section 404 compliance are associated with increased going-dark registrations, Leuz et al. (2008) conclude that this may be partly due to the effectiveness of SOX in increasing scrutiny and reducing agency costs.

\subsection{Prior research on information content and timeliness of periodic report filings}

Alford et al. (1994) show that about $20 \%$ of their sample of $10-\mathrm{K}$ filings between 1978 and 1985 are late. These firms tend to be small and experience unfavorable

\footnotetext{
${ }^{1}$ A company is an "accelerated filer" if (1) it has aggregate market value of voting and nonvoting common equity held by non-affiliates ("public float") of $\$ 75$ million or more as of the last business day of the issuer's most recently completed second fiscal quarter; (2) it has been subject to the reporting requirements of the Securities Exchange Act of 1934 for at least 12 calendar months; (3) it has previously filed at least one Form 10-K; and (4) it is not eligible to use Forms 10-KSB and 10-QSB for small businesses (SEC 2005a).

${ }^{2}$ Non-accelerated filers are required to provide a management report on the effectiveness of internal controls over financial reporting for years ending on or after 15 December 2007. Auditor attestation for non-accelerated filers has been eliminated with the passing of the Dodd-Frank Act of 2010.
} 
economic events. They also have poor operating performance, low liquidity, and high leverage. However, several contemporaneous studies present at best weak evidence that 10-K filings affect investor decisions (e.g., Stice 1991; Easton and Zmijewski 1993). Starting in 1996, filings with the SEC are electronic (the EDGAR system). Recent evidence suggests that investors view $10-\mathrm{K}$ and $10-\mathrm{Q}$ filings on EDGAR as important information events, in contrast to the pre-electronic filing era (Qi et al. 2000; Asthana and Balsam 2001; Griffin 2003; You and Zhang 2009). ${ }^{3}$

Compliance with filing deadlines has likely increased since the early $1990 \mathrm{~s}$, when electronic filing on EDGAR enhanced "the ability of companies to capture, process and disseminate" information (SEC 2002a). ${ }^{4}$ Alford et al. (1994) report that about two-thirds of late filers do not comply with Rule $12 \mathrm{~b}-25$ to file a notification and explanation of delayed filing. Since Form $12 b-25$ is available online through EDGAR, greater market pressure may have led to increased Rule 12b-25 compliance over time. EDGAR also enables investors to instantly unravel the valuation implications of a filing delay and its explanation.

Evidence in prior research of negative market reactions to Form $12 \mathrm{~b}-25$ filings suggests that 10-K filing delays signal bad news (Griffin 2003; Feldman et al. 2006; Bryant-Kutcher et al. 2007). ${ }^{5}$ This finding is consistent with evidence that the timing of earnings releases is informative and announcement delays are associated with relatively more negative earnings news (Chambers and Penman 1984; Kross and Schroeder 1984; Begley and Fischer 1998; Bagnoli et al. 2002). Griffin (2003) further finds that investors respond negatively to $10-\mathrm{K}$ and $10-\mathrm{Q}$ filings that are preceded by a Form 12b-25 filing.

Recent studies analyze the effects of SOX provisions on 10-K filing timeliness and audit report lags in the post-EDGAR era. For example, Bryant-Kutcher et al. (2007) find that, on average, for a sample of 103 late filing (calendar year-end) firms, the accelerated filing deadline of 2003 is associated with an increased incidence of late $10-\mathrm{K}$ filing and that this increase is driven by firms with weak internal controls. ${ }^{6}$ Ettredge et al. (2006) show that both initial Section 404 compliance for fiscal year 2004 and the presence of a material weakness in internal controls are associated with significant increases in audit report lags.

\footnotetext{
${ }^{3}$ Recent evidence also suggests that investors use the information in periodic reports to separate 'managed' earnings from core earnings (Balsam et al. 2002) and that corporate insiders profit from trading in anticipation of periodic report filings (Huddart et al. 2007).

${ }^{4}$ Lerman and Livnat (2010) find that about 95\% of 8-K filings during 2005-2007 are made within the prescribed filing deadline.

${ }^{5}$ Feldman et al. (2006, p. 194) document an average market reaction (cumulative abnormal returns from day -3 through day +3 ) for 9,125 Form $12 \mathrm{~b}-25$ filings of $-1.4 \%$ ( $p$ value $<0.01)$. Bryant-Kutcher et al. $(2007,23)$ document an average market reaction (day 0 through day +1$)$ for 88 Form $12 b-25$ filings of $-1.9 \%$ ( $p$ value $<0.05$ ). Griffin $(2003$, p. 436$)$ discusses the case of Northpoint Communications in November 2000, which saw its stock price decline by $12.25 \%$ after it filed a Form 12b-25.

${ }^{6}$ Bryant-Kutcher et al. (2007) rely on a relatively small sample of calendar year-end firms in 2002 and 2003 and focus on Form 12b-25 filing firms as late filers. However, not all late filers file a Form 12b-25 (Alford et al. 1994), and Rule 12b-25 compliance is not constant over time (as we show later). We determine the (large) accelerated filing status from $10-\mathrm{Ks}$ and identify firms that actually file their $10-\mathrm{K}$ beyond the statutory due date. We find no evidence of an increase in late filings for accelerated filers that filed on time in the previous year.
} 


\subsection{Hypotheses}

The SOX requirements create a tension between more reliable and more timely financial reporting. While reductions in filing deadlines are aimed at providing investors with more timely access to relevant information, significant additional tasks imposed on managers and auditors make it more difficult to comply with accelerated filing deadlines. In its initial proposal for accelerated filing, the SEC recognized that shortened filing deadlines increase the likelihood of late filing (SEC 2002b). Commenters also argued that the accelerated filing deadlines adversely affect the quality of reporting, given the reduced time for management, auditors, and boards of directors to review required reports (SEC 2003). Krishnan and Yang (2009), however, find no consistent evidence of lower quality financial reporting as a result of accelerated filing deadlines. We examine whether the reductions in filing deadlines to 75 and 60 days for accelerated filers in 2003 and large accelerated filers in 2006, respectively, are associated with an increased incidence of late filing. Our first hypothesis (in null form) is:

H1 The accelerated (large accelerated) filing deadline of 2003 (2006) is not associated with an increased incidence of late 10-K filings.

Section 404 is sometimes described as the most burdensome provision of SOX. Ettredge et al. (2006) present evidence suggesting that Section 404 compliance is associated with increased audit delays, which may in turn impair the ability to comply with accelerated filing. ${ }^{7}$ Whether the burden imposed on managers and auditors actually resulted in more late filings and requests for extensions in the first year of compliance is an empirical question. We test whether Section 404 compliance affects the timeliness of $10-\mathrm{K}$ filings. Our second hypothesis (in null form) is:

H2 Compliance with SOX Section 404 internal control requirements is not associated with an increased incidence of late filing.

Of course, late filing may itself reflect the effectiveness of internal controls. Also, because of the role of internal controls in assuring the reliability of financial reporting, weak controls increase the scope of audit work required (Hogan and Wilkins 2008). Therefore, we examine whether material internal control weakness firms are more likely to be late filers than firms with effective internal controls. If late filing is an outcome of weak internal controls, it is likely that material weakness firms drive any increase in late filing activity in years of Section 404 compliance. Our third hypothesis (in null form) is:

H3 Firms reporting a material weakness in internal controls are not more likely to file late than firms with effective internal controls.

\footnotetext{
7 As an illustration, Graphic Packaging Corporation explains the late 10-K filing as follows: "the Company has experienced delays in completing its audited financial statements for the year ended 31 December 2004 resulting from the new audit procedures required by Section 404 of the Sarbanes-Oxley Act of 2002, which have taken longer to complete than expected because this is the first year for compliance with such requirements".
} 
"Part III" of Form 12b-25 contains management's explanation for the inability to file on time. Prior research suggests that the average price reaction to Form 12b-25 notifications of late filing is negative and varies with the explanation provided by management (Feldman et al. 2006; Bryant-Kutcher et al. 2007). We extend the literature by analyzing missing explanations and explanations based on SOX internal control analyses.

If Section 404 material weaknesses are associated with late filings, explanations in Form 12b-25 may reveal information about internal control effectiveness prior to the 10-K filing. Beneish et al. (2008) analyze market reactions to material weakness disclosures. They find that Section 302 disclosures trigger negative market reactions, suggesting lower perceived reporting reliability (see also Hammersley et al. 2008); they find no price reaction for Section 404 material weakness disclosures in 10-K filings. The authors attribute this result to the lower materiality threshold for disclosures under Section 404, the richer information environments of accelerated filers or both. ${ }^{8}$ However, if material weaknesses are associated with late filings, the null finding of Beneish et al. (2008) may be explained by their focus on the 10-K audit opinion on internal controls, while the information may have been disclosed earlier in Form 12b-25. We test whether SOX internal control related explanations for filing delays in Form $12 \mathrm{~b}-25$ trigger negative price reactions. Our hypothesis (in null form) is:

H4 Material weakness disclosures in Form 12b-25 filings do not trigger negative stock price reactions.

The explanation for a late filing is not prescribed. Therefore, explanations can range from detailed narratives to a short statement that more time is needed to accumulate information. Even without prescribed guidance, however, managers face market-based incentives for full disclosure. Dye (2001) suggests that the central proposition underlying disclosure theory is that managers choose to disclose favorable information and withhold unfavorable information. Accordingly, decisions not to (fully) disclose information should be interpreted as bad news (e.g., Grossman and Hart 1980; Grossman 1981; Milgrom 1981). Many studies relax the assumptions underlying the full-disclosure result and instead offer partial disclosure equilibrium outcomes (Verrecchia 1983; Dye 1985; Wagenhofer 1990; Dutta and Trueman 2002). Consistent with a partial disclosure equilibrium, empirical evidence suggests managers tend to delay bad news disclosures relative to good news (e.g., Kothari et al. 2009). Likewise, managers facing a Form 12b-25 filing may attempt to delay disclosure of bad news by not providing a meaningful explanation on that form. Accordingly, we predict that omitting an explanation for a filing delay should be interpreted as bad news. ${ }^{9}$ Thus, our last hypothesis (in null form) is:

\footnotetext{
8 This evidence is consistent with Doyle et al. (2007b), who find no relation between accruals quality and Section 404 material weaknesses, and Ogneva et al. (2007), who find no relation between Section 404 material weakness disclosures and cost of capital. However, results are not consistent with AshbaughSkaife et al. (2008, 2009), who find a significant relation between changes in audit opinions on internal controls and changes in accruals quality and cost of capital.

9 In a similar vein, Hammersley et al. (2008) examine market reactions to Section 302 disclosures and find that nondisclosures, or "vague" disclosures, trigger more negative abnormal returns than substantive disclosures.
} 
H5 Form 12b-25 filings without explanations for the filing delay do not trigger negative stock price reactions.

\section{Sample and data}

\subsection{Sample selection and late filing classification}

We collect all firms listed on NYSE, AMEX, and NASDAQ from Compustat's Fundamentals Annual table with a link to CRSP, for fiscal years ending Dec. 31, 1999 through Dec. 31, 2006. ${ }^{10}$ This results in 41,234 firm-year observations. We drop 592 observations with no CIK on Compustat, 764 observations with no 10-K filing on EDGAR, ${ }^{11} 192$ observations without an earnings announcement date on Compustat (data item RDQ), and 1,272 observations without price or shares outstanding available on CRSP at the end of the second fiscal quarter. This procedure leads to a sample of 38,414 firm-years; of these, 36,876 firm-years have sufficient data available to compute the variables used in our regression analyses (see Sect. 4.1).

We obtain Form 12b-25 notifications of late filings from Audit Analytics' Nontimely Filer Information and Analysis table. This database comprises NT 10-K filings $^{12}$ submitted from 2000 onwards and provides an overview of the explanations for the filing delay. For the sample of 38,414 firm-years with $10-\mathrm{K}$ filings, we find 3,207 firm-years with a notification of late filing. We add 85 NT 10-K filings from EDGAR that are missing from Audit Analytics, resulting in 3,292 firm-years in which firms notify the SEC of a filing delay.

To determine late filings, we first obtain fiscal year-end dates from $10-\mathrm{K}$ reports to calculate statutory due dates. ${ }^{13}$ For years ending before 15 December 2003 , the statutory due date is the first nonholiday/business day 90 days after fiscal year-end; 10-Ks filed later than this date are late filings. For fiscal years ending on or after 15 December 2003, we classify nonsmall business filing firms with a market capitalization (measured at the end of fiscal quarter two) larger than $\$ 75$ million as "accelerated filer," and for fiscal years ending on or after 15 December 2006, we classify nonsmall business filing firms with a market capitalization larger than $\$ 700$ million as "large accelerated filer." We assign a filing deadline of 75 days to the accelerated filers, a deadline of 60 days to the large accelerated filers, and a deadline of 90 days to the remaining firm-years. We compute statutory due dates from fiscal year-ends and assigned filing deadlines. This procedure results in 4,334 late 10 -K filing observations.

The key characteristic of an accelerated (large accelerated) filer is market capitalization held by non-affiliates ("public float") of \$75 (\$700) million or more

\footnotetext{
${ }^{10}$ For fiscal 1999, we do not collect firms with fiscal years ending June through November, as the Audit Analytics NT database covers Form 12b-25 filings made from the start of 2000.

11 10-K filings can be found online at http://ftp.sec.gov. We also include 10-KSB, 10-K405, 10-KT, 10KSB40, and 10KT405 filings.

12 "NT 10-K" denotes the manner in which Form 12b-25 filings are presented in the EDGAR database.

${ }^{13}$ We use dates of fiscal year-end from the 10-Ks to calculate statutory due dates since the fiscal year-end dates in Compustat ("DATADATE") are adjusted. For example, a January 2nd year-end is coded as December 31st year-end in Compustat.
} 
Table 1 Sample selection, classification of late $10-\mathrm{K}$ filings, and classification of reason for late filings

Panel A: Sample selection

\begin{tabular}{|c|c|}
\hline Description & No. of firm-years \\
\hline NYSE, AMEX, and NASDAQ firms on Compustat/CRSP & 41,234 \\
\hline Less: No CIK on Compustat & 592 \\
\hline Less: No 10-K filing date on EDGAR & 764 \\
\hline Less: No earnings announcement date on Compustat & 192 \\
\hline Less: No CRSP market value Q2 & 1,272 \\
\hline Full firm-year sample & 38,414 \\
\hline Reduced firm-year sample with firm characteristics data available & 36,876 \\
\hline No. firm-years with notification of late filing in Audit Analytics & 3,207 \\
\hline Add: Notifications of late filing on EDGAR & 85 \\
\hline Total no. of firm-years with notification of late filing & 3,292 \\
\hline $\begin{array}{l}\text { No. of firm-years with 10-K filing classified as "late" using rough classification } \\
\text { of "accelerated filer" or "large accelerated filer" status based on CRSP market } \\
\text { value of equity at the end of Q2 }\end{array}$ & 4,217 \\
\hline $\begin{array}{l}\text { Less: companies classified as "late" and with filing deadline }<90 \text { days } \\
\text { manually checked for "accelerated filer" or "large accelerated filer," } \\
\text { misclassified in the previous step }\end{array}$ & -798 \\
\hline Total no. of firm-years with late $10-\mathrm{K}$ filing & 3,419 \\
\hline
\end{tabular}

Panel B: Distribution of 4,016 reasons for delay in 3,292 Form 12b-25 filings

\begin{tabular}{lc}
\hline Reason type & No. of firm-years \\
\hline 1. Accounting/auditing issues & 1,721 \\
2. Asset acquisitions/dispositions & 426 \\
3. Financial distress & 444 \\
4. Other & 713 \\
5. Nondisclosure & 712 \\
\hline
\end{tabular}

The sample contains firms listed on NYSE, AMEX, and NASDAQ with fiscal years ending between December 1999 and December 2006. Market value in Q2 is required to determine whether a firm is an accelerated filer (free float market value larger than $\$ 75$ million) or large accelerated filer (free float market value larger than $\$ 700$ million). The sample reduction from 38,414 to 36,876 firm-years is caused by the data requirements for control variables used in the main analysis and outlined in the "Appendix". Panel B presents the distribution of the explanations provided in Form 12b-25 filings for late filings. One filing may contain multiple explanations. The detail supporting this classification is available from the authors

as of the last business day of the issuer's most recently completed second fiscal quarter. Since we classify our firms based on total market capitalization (greater than or equal to the market value based on public float), some of our sample firms will be over-classified as (large) accelerated filers. Like Gao et al. (2009), we manually check 10-Ks for (large) accelerated filer status for 1,920 10-K filings that are classified as late and for which we determined the filing deadline to be shorter than 90 days. We find 798 observations to be misclassified as late, resulting in 3,419 10 -Ks which are actually filed after the statutory due date. These sample selection procedures are summarized in Table 1. 


\subsection{Classification of explanations in Form 12b-25 filings}

Audit Analytics condenses explanations in Forms 12b-25 narratives to 62 categories. We find that the 3,207 firm-years with Form 12b-25 filings in Audit Analytics contain 7,231 reasons, an average of 2.25 reasons per filing. We aggregate the 62 Audit Analytics categories (with the 7,231 reasons) into five categories (with 3,922 reasons). The first four categories follow Alford et al. (1994): accounting/ auditing issues; asset acquisitions/dispositions; financial distress; and other. In the accounting/auditing issues category, we include two new classes in which management relates the filing delay to implementation issues over SOX internal control assessments, identified weaknesses in internal controls or both. We add a fifth category, nondisclosure, which contains Form 12b-25 narratives with no substantive explanation. By definition, nondisclosure filings do not overlap with other categories. We manually classified 85 additional Form 12b-25 filings, found on EDGAR, distributed as follows: 45 as accounting/auditing issues, 15 as asset acquisitions/dispositions, 3 as financial distress, 24 as other, and 7 as nondisclosure. Adding these 94 reasons to the 3,922 reasons identified in Audit Analytics, we obtain 4,016 reasons for the 3,292 Form 12b-25 filings. Panel B of Table 1 describes the distribution of observations across the five categories.

\subsection{Descriptive statistics on filing delays and Rule 12b-25 compliance}

Table 2, Panel A, presents a replication of the descriptive analyses in Alford et al. (1994, 236-237). The first two columns present the distribution of 10-K filings by filing delay (the difference between the statutory due date and the filing date: $D E L A Y)$. Of 38,414 sample filings, 11,867 filings (31\%) are made on the due date $(D E L A Y=0) ; 35 \%$ are made at least 5 days before the due date; and $91 \%$ of $10-\mathrm{K}$ filings are timely $(D E L A Y \leq 0)$. This proportion exceeds the $80 \%$ reported by Alford et al. (1994). We find 283 filings $(1 \%)$ are made 1 day late $(D E L A Y=1)$; the majority of late $10-\mathrm{K}$ filings occur between day 6 and day 17 after the due date, consistent with these filings being preceded by a Form 12b-25 filing, which grants a 15-day extension.

Rule 12b-25 compliance is tabulated in the middle columns of Panel A, Table 2. Consistent with Alford et al. (1994), some firms file a notification while not being late. Of the 88 timely $10-\mathrm{K}$ filings with notifications, 60 occur on the due date, suggesting these firms anticipated a late filing but managed to file on time. Within our sample, 94\% of late filers comply with Rule 12b-25; Alford et al. (1994) report $32 \%$ compliance. Of the 215 cases $(3,419$ delayed filings $-/-3,204$ notifications) with no Form 12b-25, 107 10-Ks are filed 1 day late. ${ }^{14}$ Although a notification of late filing is due no later than 1 day after the due date, some managers may view the filing of Form 12b-25 as redundant if the firm files the 10-K on the due date of the notification. For $10-\mathrm{K}$ filings delayed by 2 days or more, compliance is $97 \%$. The two rightmost columns of Panel A present the distribution of Form 12b-25

\footnotetext{
14107 is the difference between the 283 10-K filings with a 1-day delay and the 176 filings that were accompanied by a Form 12b-25 filing.
} 
Table 2 Descriptive statistics of 10-K filings and notifications of late filing on Form 12b-25

\begin{tabular}{|c|c|c|c|c|c|c|}
\hline $10-K$ filing delay & $\begin{array}{l}\text { No. of } \\
10-K \\
\text { filings }\end{array}$ & $\begin{array}{l}\% \text { of all } \\
10-\mathrm{K} \\
\text { filings }\end{array}$ & $\begin{array}{l}\text { No. of with } \\
12 b-25 \\
\text { filings }\end{array}$ & $\begin{array}{l}\% \text { of } 10-\mathrm{K} \\
\text { filings in } \\
\text { interval }\end{array}$ & $\begin{array}{l}\text { No. of } 12 b-25 \\
\text { filings in } \\
\text { interval }\end{array}$ & $\begin{array}{l}\% \text { of all } \\
12 b-25 \\
\text { filings }\end{array}$ \\
\hline$D E L A Y \leq-5$ & 13,611 & 35 & 15 & 0 & 54 & 2 \\
\hline$D E L A Y=-4$ & 1,825 & 5 & 1 & 0 & 40 & 1 \\
\hline$D E L A Y=-3$ & 3,562 & 9 & 10 & 0 & 150 & 5 \\
\hline$D E L A Y=-2$ & 1,358 & 4 & 0 & 0 & 18 & 1 \\
\hline$D E L A Y=-1$ & 2,772 & 7 & 2 & 0 & 113 & 3 \\
\hline$D E L A Y=0$ & 11,867 & 31 & 60 & 1 & 1,322 & 40 \\
\hline Timely filings & 34,995 & 91 & 88 & 0 & 1,697 & 52 \\
\hline$D E L A Y=1$ & 283 & 1 & 176 & 62 & 1,249 & 38 \\
\hline$D E L A Y=2$ & 54 & 0 & 42 & 78 & 13 & 0 \\
\hline$D E L A Y=3$ & 97 & 0 & 69 & 71 & 202 & 6 \\
\hline$D E L A Y=4$ & 79 & 0 & 71 & 90 & 29 & 1 \\
\hline$D E L A Y=5$ & 45 & 0 & 39 & 87 & 3 & 0 \\
\hline $5<D E L A Y \leq 17$ & 2,152 & 6 & 2,124 & 99 & 54 & 2 \\
\hline $17<D E L A Y \leq 30$ & 261 & 1 & 257 & 98 & 26 & 1 \\
\hline $30<D E L A Y \leq 60$ & 142 & 0 & 139 & 98 & 13 & 0 \\
\hline $60<D E L A Y$ & 306 & 1 & 287 & 94 & 6 & 0 \\
\hline Delayed filings & 3,419 & 9 & 3,204 & 94 & 1,595 & 48 \\
\hline Total & 38,414 & 100 & 3,292 & 9 & 3,292 & 100 \\
\hline
\end{tabular}

Panel B: Distribution of filings and compliance by (Compustat) fiscal year

\begin{tabular}{|c|c|c|c|c|c|c|c|c|}
\hline & 1999 & 2000 & 2001 & 2002 & 2003 & 2004 & 2005 & 2006 \\
\hline Late filings & 343 & 536 & 414 & 392 & 321 & 634 & 484 & 295 \\
\hline$\%$ of $10-\mathrm{K}$ filings & 9 & 9 & 8 & 8 & 7 & 14 & 11 & 7 \\
\hline Late filings with $12 \mathrm{~b}-25$ filing & 309 & 501 & 388 & 375 & 287 & 591 & 466 & 287 \\
\hline Compliance $\%$ & 90 & 93 & 94 & 96 & 89 & 93 & 96 & 97 \\
\hline \multicolumn{9}{|l|}{ Accelerated filers } \\
\hline \multicolumn{5}{|l|}{ Late filings } & 101 & 440 & 326 & 233 \\
\hline \multicolumn{5}{|c|}{$\%$ of $10-\mathrm{K}$ filings by accelerated filers } & 4 & 13 & 9 & 7 \\
\hline \multicolumn{9}{|c|}{ Accelerated filers without material weakness in internal controls } \\
\hline \multicolumn{6}{|c|}{ Late filings } & 178 & 115 & 106 \\
\hline \multicolumn{6}{|c|}{$\%$ of $10-\mathrm{K}$ filings by accelerated filers without material weakness } & 6 & 4 & 4 \\
\hline \multicolumn{9}{|c|}{ Accelerated filers with material weakness in internal controls } \\
\hline \multicolumn{6}{|l|}{ Late filings } & 262 & 211 & 127 \\
\hline \multicolumn{6}{|c|}{$\%$ of $10-\mathrm{K}$ filings by accelerated filers with material weakness } & 52 & 52 & 48 \\
\hline
\end{tabular}

Panel A replicates Tables 1 and 2 in Alford et al. (1994, pp. 236-237) for the sample of 38,414 firm-years ending between December 1999 and December 2006. DELAY is the difference between the 10-K filing date and the statutory due date. A negative or zero delay indicates that the filing is timely; a positive delay indicates that the filing is late. Panel B presents the distribution of filing timeliness and Rule $12 \mathrm{~b}-25$ compliance over the sample period. Accelerated filers are firms with years ending on or after 15 December 2003, with a free float market capitalization of $\$ 75$ million or more. This classification includes large accelerated filers in 2006. These firms are required to provide auditor-attested reports on internal controls over financial reporting in the $10-\mathrm{K}$ for years ending on or after 15 November 2004. Information on disclosed material weaknesses is obtained from Audit Analytics 
filings; in total, $90 \%(52+38 \%)$ of notifications comply with the rule to file the form within 1 day of the $10-\mathrm{K}$ due date.

$10-\mathrm{K}$ filings made 18 days or more after the statutory due date represent firms that cannot file within the 15-day extension period. Firms may request an additional 15-day extension by filing an additional (amended) Form $12 \mathrm{~b}-25$. $^{15}$ In an untabulated test, we calculate a new due date for the late filers with a Form 12b25 filing $(n=3,204)$ by adding to the original due date 15 calendar days and adjusting for weekends and holidays. We find that 742 (23\%) filings do not meet the extended deadline.

Panel B of Table 2 presents descriptive statistics on the incidence of late filings and compliance with Rule $12 \mathrm{~b}-25$ by year. ${ }^{16}$ Fiscal 2003 is the year the accelerated filing deadline is effective (years ending on or after 15 December 2003); fiscal 2004 is the year accelerated filing firms are required to have audit opinions on internal controls over financial reporting (years ending on or after 15 November 2004); fiscal 2006 is the year the large accelerated filing deadline is effective (years ending on or after 15 December 2006).

The period between 1999 and 2002 shows a slight decline in the incidence of late filings from 9 to $8 \%$; in fiscal 2003, the proportion of late filers further declines to $7 \%$. These results suggest that the introduction of the 2003 accelerated filing deadline did not affect accelerated filers' ability to file on time. Late filings increase to $14 \%$ in fiscal 2004, the first year of SOX 404 compliance for accelerated filers. This finding suggests that SOX 404 implementation affected the ability to file Form $10-\mathrm{K}$ on time. The incidence of late filings declines to $11 \%$ in 2005 and $7 \%$ in 2006 , suggesting the increase in late filings in 2004 is a result of Section 404 implementation issues. The pattern in Panel B suggests that shortening the filing deadline to 60 days for large accelerated filers in fiscal 2006 did not adversely affect the incidence of late filing.

Compliance with Rule 12b-25 increased from $90 \%$ in 1999 to $96 \%$ in 2002, and declined to $89 \%$ in the first year of accelerated filing (fiscal 2003). This finding suggests that focusing on Form 12b-25 filers as late filers (Bryant-Kutcher et al. 2007; Krishnan and Yang 2009), as opposed to determining late filings based on the acual 10-K filings, results in a varying sample composition over time (relative to the population of late filers). After fiscal 2003, compliance increases up to $97 \%$ in 2006.

The lower section of Panel B provides statistics on late filings by accelerated filers. On average, the incidence of late filing is lower for accelerated filers, while the trend over time is similar to that for the total sample. The percentage of late filings by accelerated filers without a material weakness in internal controls in 2004 ( $88 \%$ of the sample) is $6 \%$, lower than the $13 \%$ for the pooled sample of accelerated filers. On the other hand, about half of firms with material weaknesses are late filers. Specifically, of the 1,178 firms reporting material internal control weaknesses during 2004 through 2006, 600 (50.9\%) are late filers. These descriptives suggest

\footnotetext{
15 For our sample of 3,204 Form 12b-25 filings of late filers, we find that 44 are followed by a second Form 12b-25 filing.

16 We use Compustat's convention of fiscal years as found in data item "FYEAR." That is, fiscal years ending January through May are coded as the prior calendar year, and fiscal years ending June through December are equal to the current calendar year.
} 
that firms with weak internal controls drive the increase in firms that do not comply with the accelerated filing requirements in the first year of Section 404 compliance.

\section{Model}

\subsection{Regression model for late filing incidence}

This section presents a multivariate regression framework that controls for firm characteristics related to late filing. By definition, accelerated filers are larger than non-accelerated filers. Since smaller firms are more likely to file late (Alford et al. 1994; Bryant-Kutcher et al. 2007), not controlling for firm size works against finding evidence of an effect of the SOX provisions on late filing. We control for size using the natural logarithm of market capitalization at year-end, $\ln (M V) .{ }^{17} \mathrm{We}$ control for leverage $(L E V)$ because of financial distress related explanations for filing delays in Form 12b-25 filings and the previously documented association with late filing (Alford et al. 1994). Given that late filers perform poorly (Alford et al. 1994), we control for fiscal year stock price changes (BHAR) and the incidence of losses (LOSS). Because of differences in rules governing late filings across exchanges, we create three indicator variables (NYSE, AMEX, NASDAQ) to control for exchange-listing effects.

Ge and McVay (2005) and Doyle et al. (2007a) find that firms reporting a material weakness in internal controls have greater business complexity, are smaller, have lower earnings performance, and are more likely hiring a large audit firm. We create an indicator variable $(B I G N)$ capturing whether a company hires a Big $\mathrm{N}$ auditor, because we expect greater pressure from large auditors for timely filing. ${ }^{18}$ Business complexity affects the effort needed to gather and verify information and thus potentially increases filing delays (e.g., Ettredge et al. 2006). We control for business complexity as the number of reported segments (BUSSEG). ${ }^{19}$ We control for the effects of mergers and acquisitions $(M \& A)$ and restructuring charges (RESTRUCT) since prior research has found these activities to be related to internal control weaknesses (Ashbaugh-Skaife et al. 2007; Doyle et al. 2007a) and both are factors named in management's explanations for filing delays. Ashbaugh-Skaife et al. (2007) predict and find that auditor resignations in 2003 are associated with a higher likelihood of internal control deficiencies. Given that auditor changes affect audit report lags (Schwartz and Soo 1996a), we include an indicator variable capturing an auditor change ( $\triangle A U D I T O R)$. Lastly, we include the number of 8 -K filings made on EDGAR during the 365 days before the statutory due date (FILINGS_8K). In addition to auditor changes, 8-K filings disclose material events such as bankruptcy proceedings, significant asset acquisitions,

\footnotetext{
17 Information on the construction of these variables is provided in the "Appendix".

18 Schwartz and Soo (1996b) find that the timeliness of 8-K filings disclosing auditor changes is affected by the new audit firm being a Big $\mathrm{N}$ or non-Big $\mathrm{N}$ firm. Filing delays are greater and late filing occurs more often when non-Big $\mathrm{N}$ auditors are involved.

19 Controlling for the existence of foreign sales as a measure of business complexity has no qualitative influence on the results.
} 
material impairments, and control changes (Lerman and Livnat 2010). Consistent with Alford et al. (1994), we anticipate the number of material economic events to affect filing delays. ${ }^{20}$

Using these control variables we develop the following base model of late filing determinants:

$$
\begin{aligned}
\text { NEWLATE }_{i t}= & \beta_{0}+\beta_{1} \ln \left(M V_{i t}\right)+\beta_{2} L E V_{i t}+\beta_{3} \text { BHAR }_{i t}+\beta_{4} L_{O S S_{i t}}+\beta_{5} A M E X_{i t} \\
& +\beta_{6} \text { NASDAQ }_{i t}+\beta_{7} \text { BIGN }_{i t}+\beta_{8} \text { BUSSEG }_{i t}+\beta_{9} M \& A_{i t} \\
& +\beta_{10} \text { RESTRUCT }_{i t}+\beta_{11} \Delta \text { AUDITOR } \\
&
\end{aligned}
$$

where all variables are defined in the "Appendix". The dependent variable (NEWLATE) is an indicator variable equal to one if the $10-\mathrm{K}$ is filed beyond the statutory due date and zero otherwise. To examine whether the accelerated filing deadlines (2003 and 2006) and Section 404 implementation (2004) result in late filings for firms that were previously able to file on time, we exclude firms that filed late in the previous year $(L A T E M 1=1)$, and we add indicator variables for accelerated filing requirements in 2003 (AF2003) and 2006 (LAF2006) and Section 404 compliance in 2004 through 2006 (IC2004-IC2006). The model is estimated using logit regressions including controls for year and industry fixed effects. Because of the panel structure of our data and the persistence of our firmspecific variables, standard errors are adjusted for heteroskedasticity and clustering at the firm level (Petersen 2009). The NYSE indicator variable is excluded to preclude perfect collinearity.

\subsection{Descriptive statistics for timely and late filers}

Table 3 reports mean and median values for the variables used in our base model for timely and late filing firms. For the sample of 36,876 firm-years with the data needed to estimate our base model, 3,248 (9\%) have a late 10-K filing while 33,628 $(91 \%)$ are timely. Of timely firm-years, $5 \%$ had a late filing in the previous year, while $32 \%$ of current late filers were also late in the prior year. As a result, our dependent variable NEWLATE, which measures the incidence of late filings by firms that previously filed on time, is set to 0 for $31,985(94 \%)$ observations and set to 1 for 2,206 observations (6\%).

Consistent with Alford et al. (1994), Table 3 shows that late filing firms are smaller $(\ln (M V))$, have higher leverage $(L E V)$, are more likely to report a loss $(L O S S)$, and experience more negative news during the year; mean fiscal year buyand-hold abnormal returns $(B H A R)$ are 0.03 for timely filers and -0.25 for late filers. In addition, late filing firms are less likely to have a large auditor $(B I G N)$, are more likely to change their auditor $(\triangle A U D I T O R)$, engage in restructuring (RESTRUCT), and have more 8-K filings on EDGAR (FILINGS_8 K). Exchange

\footnotetext{
${ }^{20}$ Alford et al. (1994) use the extreme deciles of annual abnormal stock returns as proxies for economic events.
} 
Table 3 Descriptive statistics for timely 10-K filings and delayed 10-K filings

\begin{tabular}{|c|c|c|c|c|c|c|}
\hline \multirow[t]{2}{*}{ Variable } & \multicolumn{3}{|l|}{ Timely firms } & \multicolumn{3}{|l|}{ Late firms } \\
\hline & No. of obs. & Mean & Median & No. of obs. & Mean & Median \\
\hline \multicolumn{7}{|c|}{ Timeliness variables } \\
\hline$L A T E$ & 33,628 & 0.00 & 0.00 & 3,248 & 1.00 & 1.00 \\
\hline LATEM1 & 33,628 & 0.05 & 0.00 & 3,248 & 0.32 & 0.00 \\
\hline NEWLATE & 31,985 & 0.00 & 0.00 & 2,206 & 1.00 & 1.00 \\
\hline \multicolumn{7}{|c|}{ Firm characteristics } \\
\hline $\ln (M V)$ & 33,628 & 5.68 & 5.63 & 3,248 & 4.13 & 3.96 \\
\hline$L E V$ & 33,628 & 0.22 & 0.17 & 3,248 & 0.29 & 0.23 \\
\hline BHAR & 33,628 & 0.03 & -0.06 & 3,248 & -0.25 & -0.36 \\
\hline LOSS & 33,628 & 0.29 & 0.00 & 3,248 & 0.63 & 1.00 \\
\hline NYSE & 33,628 & 0.34 & 0.00 & 3,248 & 0.17 & 0.00 \\
\hline$A M E X$ & 33,628 & 0.08 & 0.00 & 3,248 & 0.17 & 0.00 \\
\hline$N A S D A Q$ & 33,628 & 0.58 & 1.00 & 3,248 & 0.67 & 1.00 \\
\hline$B I G N$ & 33,628 & 0.76 & 1.00 & 3,248 & 0.63 & 1.00 \\
\hline BUSSEG & 33,628 & $1.93^{\mathrm{a}}$ & $1.00^{\mathrm{b}}$ & 3,248 & $1.87^{\mathrm{a}}$ & $1.00^{\mathrm{b}}$ \\
\hline$M \& A$ & 33,628 & $0.36^{\mathrm{a}}$ & $0.00^{\mathrm{b}}$ & 3,248 & $0.37^{\mathrm{a}}$ & $0.00^{\mathrm{b}}$ \\
\hline RESTRUCT & 33,628 & 0.17 & 0.00 & 3,248 & 0.19 & 0.00 \\
\hline$\triangle A U D I T O R$ & 33,628 & 0.08 & 0.00 & 3,248 & 0.17 & 0.00 \\
\hline FILINGS_8 K & 33,628 & 6.73 & 5.00 & 3,248 & 7.27 & 5.00 \\
\hline$M W I C$ & 8,281 & 0.07 & 0.00 & 873 & 0.63 & 1.00 \\
\hline
\end{tabular}

Descriptive statistics for the sample of 36,876 firm-years ending between December 1999 and December 2006. All variables are defined as in the "Appendix"; continuous variables are winsorized to the 1 st and 99th percentiles of their distributions. Late firm-years are fiscal years for which the subsequent 10-K filing occurs later than the statutory due date $(L A T E=1)$; all other firm-years are marked as timely $(L A T E=0) . N E W L A T E$ is available for 34,191 observations where the firm was not late in the previous year $(L A T E M 1=0)$

a Mean value for late firms is not significantly different from the mean for timely firms at the 0.01 level or better (two-tailed), based on a $t$ test

b Median value for late firms is not significantly different from the median for timely firms at the 0.01 level or better (two-tailed), based on a Wilcoxon rank-sum test

listing variables suggest that late filers are less likely listed on NYSE, while more likely listed on AMEX or NASDAQ.

Table 3 further provides descriptives for an indicator variable for Section 404 material weakness disclosures $(M W I C)$, available for accelerated filers with fiscal years ending on or after 15 November 2004. This variable is equal to one if the firm disclosed an auditor attested material weakness in internal controls as identified by Audit Analytics and zero otherwise. Of the 873 late filing firms required to report under Section 404, more than half (63\%) report a material weakness in internal controls. On the other hand, of all 8,281 timely firms complying with Section 404, $7 \%$ report a material weakness. These findings complement the descriptive analyses in Table 2 and suggest that weak internal controls are associated with less timely 10-K filings. 
Table 4 presents pairwise and rank correlations between the dependent and control variables included in Eq. 1 for the 34,191 observations with NEWLATE available. NEWLATE is most strongly correlated with firm size $(\ln (M V))$, stock returns $(B H A R)$, losses $(L O S S)$, and material weaknesses $(M W I C)$. Firm size is correlated with all other variables. An analysis of variance inflation factors reveals that none of the explanatory variables has a variance inflation factor value larger than 10 (maximum value: 2.35), suggesting that multicollinearity is not a serious concern.

\section{Results}

\subsection{The impact of accelerated filing and SOX Section 404 on 10-K filing timeliness}

Table 5 presents results of tests of our first three hypotheses. We estimate Eq. 1 and add indicator variables and interactions. Model 1 presents the base model results. Consistent with expectations, smaller and more highly levered firms are more likely to file late; control variables related to performance reveal that firms filing late perform poorly as indicated by fiscal year stock returns and loss incidence. We find no significant difference in late filing behavior across the exchanges. ${ }^{21}$ After controlling for other firm characteristics, companies that hire a large auditor are not less likely to file late in the current year. ${ }^{22}$ The control variables related to complexity show that the presence of mergers and acquisitions and the number of business segments adversely affect the timeliness of $10-\mathrm{K}$ filings. Restructuring charges have a weaker effect on late filing. Lastly, significant events reflected in 8-K filings significantly affect the incidence of new late filings.

In Model 1a we add indicator variables for the accelerated filing deadline of 2003 (AF2003) and large accelerated filing deadline of 2006 (LAF2006). Inconsistent with claims that the accelerated filing deadline increases the incidence of late filings, we find no significant association between AF2003 and NEWLATE. On the other hand, we find a significant effect of the large accelerated filing deadline of 2006 on timely filing, suggesting that more large accelerated filers that were previously on time were not able to comply with the tighter deadline of 60 days.

Anecdotal evidence suggests that large accelerated filer timeliness in fiscal 2006 may be related to the options backdating scandal discovered in 2006 (Graybow 2007; Taub and Cook 2007). We collect a list of firms allegedly involved in options

\footnotetext{
${ }^{21}$ In untabulated tests, we analyzed the determinants of firms filing late beyond the extension period granted by filing Form 12b-25. Test results suggest that firms listed on NASDAQ are significantly less likely to file after the granted extension period. This result is consistent with different rules applied by the exchanges regarding the filing of 10-Ks after firms have notified the SEC of a delay in accordance with Rule 12b-25. For example, NYSE monitors firms after they miss the extension period deadline but allows companies an additional nine months to file the annual report. NASDAQ applies more sanctions and forces firms to file as soon as possible (SEC 2005b).

22 This result can be explained by our focus on firms that did not file late in the previous year. Untabulated tests reveal that when base model (1) is estimated for the full sample with LATE as the dependent variable, the coefficient on $B I G N$ is negative and significant.
} 


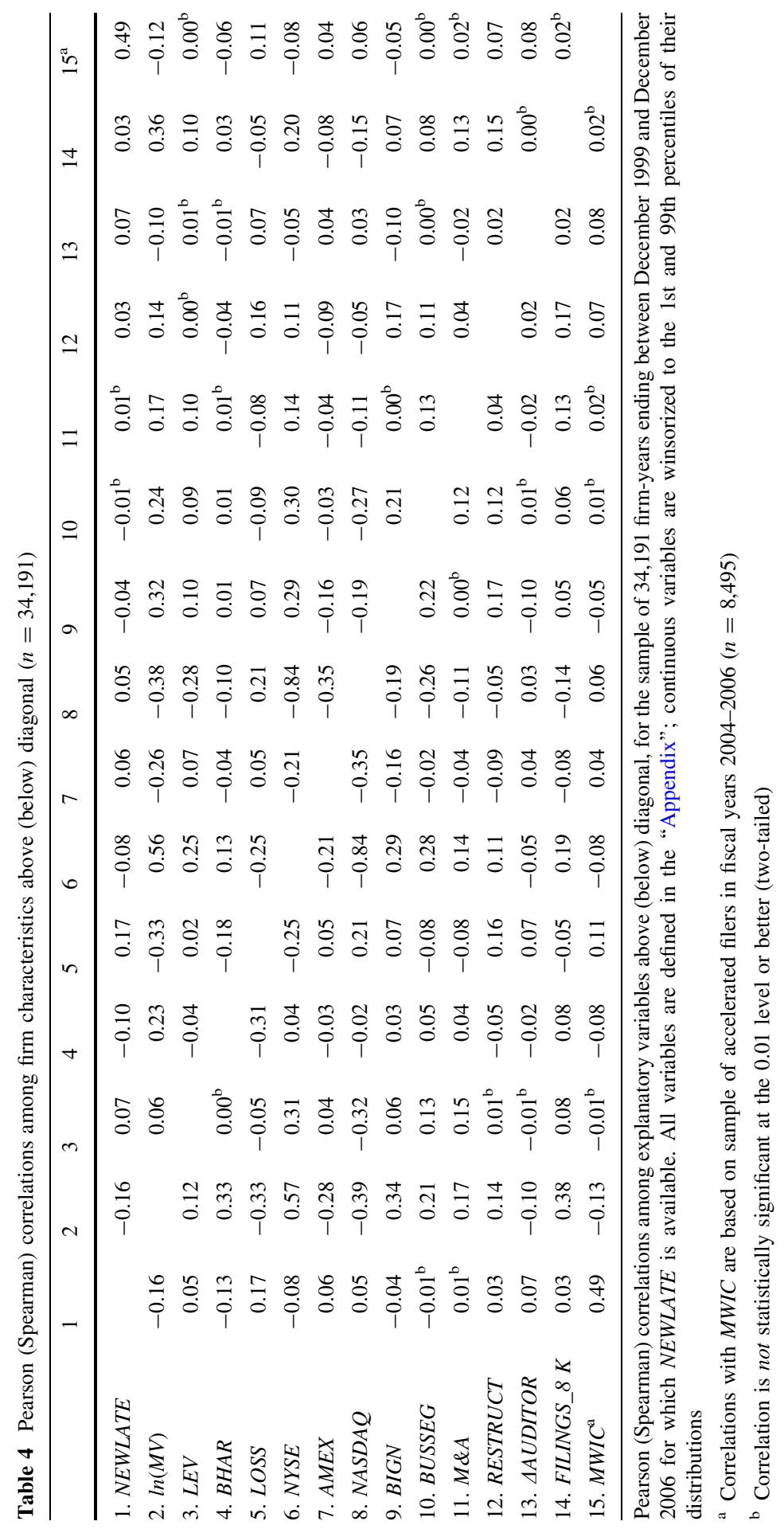


Table 5 Effects of SOX provisions on late filings

\begin{tabular}{|c|c|c|c|c|c|}
\hline Dependent variable & $\begin{array}{l}\text { Model } 1 \\
\text { NEWLATE }\end{array}$ & $\begin{array}{l}\text { Model 1a } \\
\text { NEWLATE }\end{array}$ & $\begin{array}{l}\text { Model 1b } \\
\text { NEWLATE }\end{array}$ & $\begin{array}{l}\text { Model 1c } \\
\text { NEWLATE }\end{array}$ & $\begin{array}{l}\text { Model 1d } \\
\text { NEWLATE }\end{array}$ \\
\hline \multicolumn{6}{|l|}{ Test variables } \\
\hline$A F 2003$ & & 0.186 & 0.197 & & \\
\hline LAF2006 & & $0.546 * * *$ & 0.313 & & \\
\hline BD2006 & & & $3.161 * * *$ & $3.147 * * *$ & $3.174 * * *$ \\
\hline IC2004 & & & & $0.938 * * *$ & -0.033 \\
\hline IC2005 & & & & $0.629 * * *$ & $-0.316^{*}$ \\
\hline IC2006 & & & & $0.953 * * *$ & 0.302 \\
\hline$M W I C * I C 2004$ & & & & & $2.775 * * *$ \\
\hline$M W I C * I C 2005$ & & & & & $3.261 * * *$ \\
\hline$M W I C * I C 2006$ & & & & & $2.927 * * *$ \\
\hline \multicolumn{6}{|l|}{ Control variables } \\
\hline $\ln (M V)$ & $-0.317 * * *$ & $-0.324 * * *$ & $-0.330 * * *$ & $-0.374 * * *$ & $-0.368 * * *$ \\
\hline$L E V$ & $1.019 * * *$ & $1.015 * * *$ & $1.027 * * *$ & $1.006 * * *$ & $1.048 * * *$ \\
\hline$B H A R$ & $-0.315^{* * *}$ & $-0.311 * * *$ & $-0.307 * * *$ & $-0.270^{* * *}$ & $-0.263 * * *$ \\
\hline LOSS & $0.817 * * *$ & $0.821 * * *$ & $0.827 * * *$ & $0.837 * * *$ & $0.849 * * *$ \\
\hline$A M E X$ & 0.064 & 0.076 & 0.052 & 0.090 & 0.031 \\
\hline$N A S D A Q$ & 0.056 & 0.068 & 0.043 & 0.030 & -0.011 \\
\hline$B I G N$ & -0.027 & -0.034 & -0.036 & -0.105 & -0.049 \\
\hline BUSSEG & 0.045 & $0.045 * *$ & $0.045^{* *}$ & $0.049 * *$ & $0.039 *$ \\
\hline$M \& A$ & 0.291 & $0.292 * * *$ & $0.300 * * *$ & $0.311 * * *$ & $0.298 * * *$ \\
\hline RESTRUCT & 0.145 & $0.143 * *$ & $0.131 * *$ & $0.118 *$ & 0.040 \\
\hline$\triangle A U D I T O R$ & 0.527 & $0.527 * * *$ & $0.536 * * *$ & $0.540 * * *$ & $0.503 * * *$ \\
\hline FILINGS_8K & 0.025 & $0.024 * * *$ & $0.023 * * *$ & $0.018 * * *$ & $0.013 * *$ \\
\hline Year dummies & Included & Included & Included & Included & Included \\
\hline Industry dummies & Included & Included & Included & Included & Included \\
\hline$n$ & 34,191 & 34,191 & 34,191 & 34,191 & 34,191 \\
\hline Pseudo $R^{2}$ & 0.136 & 0.137 & 0.142 & 0.148 & 0.202 \\
\hline
\end{tabular}

Logit regressions with standard errors adjusted for heteroskedasticity and clustering by firm (Petersen 2009). *,**, *** Denote statistical significance at the $0.10,0.05$, and 0.01 level, respectively, based on two-tailed tests. All variables are defined in the "Appendix", and continuous variables are winsorized to the 1st and 99th percentiles of their distributions. Year dummies are based on the Compustat fiscal year convention. Industry dummies are constructed using one-digit SIC codes

backdating from The Wall Street Journal (2007) and create an indicator variable BD2006, equal to one for fiscal 2006 firms included in this list. Of the 73 firms matched with our sample, 36 qualify as large accelerated filers in 2006 (3\% of large accelerated filers). When we add BD2006 to the regression in Model 1b, the significant effect of the large accelerated filing deadline disappears. This finding is consistent with the results for accelerated filing in 2003 and suggests that, notwithstanding the costs of accelerating, the tighter deadlines have on average not resulted in more firms filing late. 
In Model 1c we add indicator variables IC2004-2006, which equal one if the firm complies with Section 404 in the respective year and zero otherwise. We find that in all three years compliance with the internal control provisions increases late filing incidence. This finding is consistent with Ettredge et al. (2006), who find an increase in audit report lags for accelerated filers in 2004. The increased audit report lags thus appear to result in more late 10-K filings in 2004 through 2006. However, when we control for material weaknesses in internal controls by adding interactions of these variables with $M W I C$ in Model 1d (MWIC*IC2004-2006), we find that the coefficients on these interaction terms are positive and significant, whereas variables IC2004-2006 are no longer significantly positive. This implies that Section 404 compliance does not affect the ability to file on time for the majority of firms without a material weakness in internal controls.

Our result is not consistent with Ettredge et al.'s (2006) prediction that increased audit report lags affect $10-\mathrm{K}$ filing timeliness for material weakness firms as well as effective internal control firms. Consistent with our results for accelerated filing requirements, our findings suggest that the internal control provisions under Section 404 did not increase the incidence of late filing for firms that did not suffer from internal control weaknesses. In the context of the trade-off between more reliable and more timely financial reporting, we find evidence of a Section 404 impact on 10-K filing delays only for firms with a material weakness in internal controls, that is, the firms for which the provisions are most crucial.

To summarize, we find no evidence to reject $H 1$. The evidence shows no association between an increased incidence of late filing and the accelerated (large accelerated) filing deadline of 2003 (2006). Also, although $H 2$ is rejected-in that Section 404 compliance is associated with significantly more late filings in 2004 through 2006-further analyses reveal that firms with material weaknesses in internal controls are responsible for the increase in late filings. Thus, we reject $H 3$. The majority of accelerated filing firms with effective internal controls do not show an increase in late filing in the years of Section 404 compliance. These findings confirm that the inability to file on time in itself signals the ineffectiveness of internal controls over financial reporting.

\subsection{Market reactions to form $12 \mathrm{~b}-25$ filings and explanations of late filings}

To probe the association between material weaknesses in internal controls and late filing of Form 10-K, we examine whether notifications of late filings provide information to investors about the effectiveness of internal controls prior to official disclosure in the forthcoming $10-\mathrm{K}$. We analyze market reactions to Form 12b-25 filings by computing cumulative abnormal returns over days 0 to +1 relative to the filing date; daily abnormal returns are the difference between raw daily CRSP cumdividend returns and the average returns of similar sized firms using the NYSE/ AMEX/NASDAQ year-end cutoffs (CRSP file "erdport1"). Our choice for this twoday event window is supported by results of untabulated tests, which examine mean absolute abnormal daily stock return and cumulative abnormal stock returns for the days around notifications of late filing. The analyses suggest that reactions to these filings occur mainly on days 0 and +1 , consistent with Griffin (2003) for 10-K filings. 
Table 6 presents average market reactions to Form $12 \mathrm{~b}-25$ filings for the full sample and for five disclosure categories. Our sample consists of 2,793 Form 12b-25 filings with sufficient data to compute abnormal returns and where the 10-K filing occurs at least 2 days after the Form $12 \mathrm{~b}-25$ filing. While a Form $12 \mathrm{~b}-25$ can contain multiple reasons for late filing, $80 \%$ of the firms provide only one category of reason for filing late. Panel A presents the average market reaction for the full sample and the sample with a single type of reason. By construction, filings in the nondisclosure category have a single reason.

The average price reaction (CARNT) for the sample including observations with multiple reasons is $-1.03 \%$. Each of the five categories of explanations results in a negative and significant abnormal return. Filings including accounting/auditing explanations have the least negative CARNT $(-0.83 \%)$, while filings including financial distress as a reason trigger the most negative reaction $(-2.11 \%)$. For filings that include a single type of reason, the average CARNT is $-0.79 \%$. This implies that investors interpret multiple reasons for late $10-\mathrm{K}$ filings more negatively than a single reason. For the sample that provides only one reason for the late 10-K filing, we find that the filings with accounting/auditing issues explanations trigger a significant and negative market reaction, and the nondisclosure category triggers the most negative and significant price reaction $(-1.44 \%)$. Abnormal returns associated with other reasons are not significantly different from zero. For example, it appears as if financial distress explanations trigger price declines only in conjunction with other types of reasons.

As outlined earlier, the accounting/auditing issues category includes SOX internal control related explanations: issues with the implementation of Section 302 or 404 internal control requirements, or material weakness issues with ICFR (internal controls over financial reporting) or DC (disclosure controls) preparation. For filings including either explanation, we set an indicator variable labeled ICSOX equal to one and zero otherwise. In panel B of Table 6, we split the accounting/ auditing issues category into filings with and without ICSOX explanations. We find that the CARNT of non-ICSOX accounting/auditing related filings is not significantly different from zero, whereas filings with ICSOX-related reasons on average have a CARNT of $-1.28 \%$, significant at the $1 \%$ level. We further decompose SOXrelated reasons and find average market reactions of -1.13 and $-1.35 \%$ for implementation and material weakness explanations, respectively; both are significant at the $5 \%$ level.

To summarize, we reject $H 4$ and find that when management provides an explanation in its Form $12 \mathrm{~b}-25$ filing for a $10-\mathrm{K}$ filing delay that is related to internal control implementation issues, material weaknesses or both, the market reacts negatively. Thus, given the association between material weaknesses and late filing, the evidence suggests that material weakness disclosures are associated with downward belief revisions about firm value prior to the $10-\mathrm{K}$ report on internal control effectiveness. This finding has implications for capital market research on Section 404 material weakness disclosures that relies on the $10-\mathrm{K}$ filing date as event date (e.g., Beneish et al. 2008). Similarly, we reject $H 5$ and find that nondisclosures are associated with significantly negative market reactions. This evidence is consistent with theory predicting that incomplete disclosures are viewed 
Table 6 Market reactions to Form 12b-25 filings and explanations

\begin{tabular}{llllll}
\hline & \multicolumn{2}{l}{ Multiple reasons } & & \multicolumn{2}{l}{ Single reason } \\
\cline { 5 - 6 } & $n$ & & CARNT $(\%)$ & & CARNT $(\%)$ \\
\hline
\end{tabular}

Panel A: Average market reactions to late filing notifications for total sample split by explanation for multiple (overlapping) and single reasons provided

$\begin{array}{lrrrc}\text { All 12b-25 filings } & 2,793 & -1.03 * * * & 2,236 & -0.79 * * * \\ \text { Explanations } & & & & \\ \text { 1. Accounting/auditing issues } & 1,552 & -0.83 * * * & 1,204 & -0.74 * * * \\ \text { 2. Asset acquisitions/dispositions } & 364 & -1.46 * * * & 145 & -0.85 \\ \text { 3. Financial distress } & 374 & -2.11 * * * & 112 & -0.09 \\ \text { 4. Other } & 578 & -1.16 * * & 215 & 0.32 \\ \text { 5. Nondisclosure } & 560 & -1.44 * * * & 560 & -1.44 * * *\end{array}$

Panel B: Average market reactions to late filing notifications for accounting/auditing related issues split by SOX internal control related explanation

Accounting/auditing issues
a. $I C S O X=0$
1,125
$-0.57 *$
865
$-0.53$
b. $I C S O X=1$
427
$-1.52 * * *$
339
$-1.28 * * *$
b1. $I C S O X=1$ : implementation ${ }^{a}$
342
$-1.35^{* * *}$
278
$-1.13 * * *$
b2. $I C S O X=1$ : material weakness ${ }^{\text {b }}$
174
$-1.86^{* * *}$
119
$-1.35^{* *}$

The sample of 2,793 notifications results from the 3,292 notifications identified in Table 1 minus firms without the required returns data available minus firms with a 10-K filing less than 2 days after the Form 12b-25 filing. Abnormal returns are computed as the difference between the raw (cum-dividend) daily return from CRSP and the average daily return of similar sized firms as identified by the NYSE/AMEX/ NASDAQ year-end cutoffs (CRSP file "erdport1"). Explanations are defined in Table 1 and are not mutually exclusive, except for the nondisclosure category. *, **,*** Denote statistical significance at the $0.10,0.05$, and 0.01 level, respectively, based on two-tailed tests

${ }^{\text {a }}$ ICSOX = 1: implementation refers to cases with "internal control or Section 302/404 implementation issues" explanations

b $I C S O X=1$ : material weakness refers to cases with "material weakness issues with ICFR or DC preparation" explanations

as bad news (e.g., Dye 2001). It is also in line with Hammersley et al. (2008), who find that market reactions to Section 302 material weakness disclosures are more negative when disclosures are vague, that is, when firms do not disclose sufficient information for investors to understand the source or importance of the weakness.

\subsection{Additional tests on the market reaction to material weakness disclosures}

To provide more evidence on the effect of Form 12b-25 filings on the capital market implications of Section 404 material weakness disclosures, we perform two additional (untabulated) tests. First, we test the association between the market reaction to ICSOX-related explanations in Form 12b-25 and the likelihood of subsequent material weakness disclosures in the 10-K. Second, we test the association between preempting Form 12b-25 filings and the market response to subsequent $10-\mathrm{K}$ filings for material weakness firms. 
Our first additional test builds on a model including variables predicting Section 404 material weaknesses (Ge and McVay 2005; Ashbaugh-Skaife et al. 2007; Doyle et al. 2007a). To this model we add an indicator variable for Form 12b25 filers, an ICSOX indicator variable, CARNT, capturing the market reaction to Form 12b-25 filings (equals 0 for non-12b-25 filers), and an interaction between CARNT and ICSOX. ICSOX captures the extent to which internal control related explanations for filing delays are associated with actual material weakness disclosures in the subsequent $10-\mathrm{K}$ filing. The interaction captures the extent to which material weakness disclosures are reflected into market prices upon disclosure of these explanations in Form $12 b-25 .^{23}$

After controlling for other determinants, results reveal a significantly positive association between Form 12b-25 filings and material weakness disclosures ( $p$ value $<0.01)$. Further, we find a positive and significant incremental effect of ICSOX ( $p$ value $<0.05$ ), suggesting ICSOX explanations are associated with an increased likelihood of material weakness disclosure. While there is no significant association between $C A R N T$ and $M W I C$, the interaction between CARNT and ICSOX is significantly negative $(p$ value $<0.01)$. In other words, more negative market reactions to ICSOX-explanations in Form 12b-25 imply a higher likelihood of subsequent material weakness disclosure in the 10-K. Form $12 \mathrm{~b}-25$ filings thus preemptively disclose some Section 404 material weaknesses and trigger negative stock market reactions before the 10-K filing date.

In our second additional test, we examine market reactions to $10-\mathrm{K}$ filings for Section 404 complying firms. On average, firm-years without a material weakness have a negative $10-\mathrm{K}$ market reaction of $-0.13 \%$ on the $10-\mathrm{K}$ filing file date through the day after. Like Beneish et al. (2008), our 1,074 10-K filings including material weakness disclosures do not trigger more negative abnormal returns $(-0.08 \%)$. However, when we split our sample into groups with $(n=533)$ and without ( $n=541)$ a preceding Form $12 \mathrm{~b}-25$ filing, we find average $10-\mathrm{K}$ market reactions of $0.30 \%$ and $-0.47 \%$, respectively. The difference between these market reactions is statistically significant $(p$ value $<0.05$ ) and suggests that timely material weakness firms have lower market reactions to 10 -K filings relative to late material weakness firms filing a preemptive Form 12b-25.

Multivariate analysis, which controls for other determinants of the market reaction to $10-\mathrm{K}$ filings, shows a significant difference in market reaction to $10-\mathrm{K}$ filings between timely and late material weakness firms of $-1.19 \%$ ( $p$ value $<0.01)$. Combined with the finding that market reactions to Form $12 \mathrm{~b}-25$ filings are related to subsequent material weakness disclosure, these findings highlight the importance of focusing on event dates other than $10-\mathrm{K}$ dates in an examination of the market reaction to Section 404 material weakness disclosures.

\footnotetext{
${ }^{23}$ The model, with $M W I C$ as dependent variable, is estimated using logit regression for a sample of 9,154 firm-year observations in fiscal 2004 through 2006 complying with Section 404.
} 


\section{Summary and conclusions}

This paper examines the timeliness of $10-\mathrm{K}$ filings. Motivated by regulatory changes after SOX that impose a tension between more reliable and more timely financial reporting, we test if the accelerated filing deadlines effective in 2003 and 2006 as well as the Section 404 internal control disclosure requirements effective in 2004 are associated with an increased incidence of late 10-K filing. In addition, we examine the market reactions to explanations of filing delays, particularly explanations related to SOX compliance, weaknesses in internal controls or both.

Using a sample of 10-K filings for years ending between 1999 and 2006, we find that $9 \%$ of $10-\mathrm{K}$ filings are late and that, in $94 \%$ of these cases, firms comply with Rule $12 \mathrm{~b}-25$ to notify the SEC of the delay by filing a Form 12b-25. Inconsistent with claims that increased duties imposed on auditors and management by SOX impair the ability of firms to comply with accelerated filing deadlines, we find no evidence that the accelerated deadlines of 2003 and 2006 affect late 10-K filings by firms that previously filed on time. Similar evidence is found for accelerated filers that are required to comply with Section 404 and have effective internal controls. A sharp increase in late filing for fiscal 2004 firm-years, however, is driven by firms that disclose material weaknesses in internal controls.

Further, we provide new evidence on the information content of management disclosures in Form 12b-25 filings. Consistent with disclosure theory and incentives to withhold bad news, notifications without a meaningful explanation for the late $10-\mathrm{K}$ filing are associated with negative stock price reactions. While about half of all material weakness firms are late $10-\mathrm{K}$ filers and managers provide internal control related explanations in Form 12b-25 narratives, we show that material weakness disclosures negatively affect market prices prior to the auditor's $10-\mathrm{K}$ report. Also, market reactions to $10-\mathrm{K}$ filings for material weakness firms are weaker when preempted by a notification of late filing. These findings suggest that Section 404 material weakness disclosures affect investor decisions. Our results imply that future research focusing on the market reaction to Section 404 disclosures should take into consideration the potentially preemptive effect of late filing notifications.

Acknowledgments We thank the editor (Katherine Schipper), an anonymous referee, Matt Bonnet, Idil Burat, Igor Goncharov, Abe de Jong, Aneel Keswani, Robert Lensink, Vicky Kiosse, Gilad Livne, Peter Pope, Jeroen Suijs, Sander van Triest, Steve Young, and workshop participants at Groningen University, Rotterdam School of Management, and Cass Business School for their invaluable comments.

Open Access This article is distributed under the terms of the Creative Commons Attribution Noncommercial License which permits any noncommercial use, distribution, and reproduction in any medium, provided the original author(s) and source are credited.

\section{Appendix}

See Table 7. 
Table 7 Variable definitions

\begin{tabular}{|c|c|}
\hline Variable & Description \\
\hline DELAY & $\begin{array}{l}\text { Difference in days between } 10-\mathrm{K} \text { filing date and statutory due date, where the statutory } \\
\text { due date is calculated as the first nonholiday/business day at least } 90 \text { (or } 75 \text { for } \\
\text { accelerated filers, } 60 \text { for large accelerated filers) days after the firm's fiscal year-end }\end{array}$ \\
\hline$L A T E$ & Equal to 1 if firm files $10-\mathrm{K}$ after the statutory due date, 0 otherwise \\
\hline LATEM1 & Equal to 1 if firm files $10-\mathrm{K}$ after the statutory due date in the previous year, 0 otherwise \\
\hline NEWLATE & $\begin{array}{l}\text { Variable available only for observations with } L A T E M 1=0 \text {; equal to } 1 \text { if firm files } 10-\mathrm{K} \\
\text { after the statutory due date, } 0 \text { otherwise }\end{array}$ \\
\hline $\ln (M V)$ & Natural logarithm of market capitalization at year-end (Compustat PRCC_F*CSHO) \\
\hline$B T M$ & $\begin{array}{l}\text { Book value of equity (CEQ) divided by market capitalization at fiscal year-end } \\
\text { (PRCC_F*CSHO) }\end{array}$ \\
\hline$L E V$ & Ratio of long-term debt (DLTT+DLC) to total assets (AT) \\
\hline BHAR & $\begin{array}{l}\text { Size-adjusted fiscal year buy-and-hold returns from CRSP using the NYSE/AMEX/ } \\
\text { NASDAQ year-end capitalization deciles (ermport1) }\end{array}$ \\
\hline LOSS & Equal to 1 if firm reports negative income before extraordinary items (IB), 0 otherwise \\
\hline NYSE & Equal to 1 if firm is listed on NYSE, 0 otherwise (CRSP) \\
\hline AMEX & Equal to 1 if firm is listed on AMEX, 0 otherwise (CRSP) \\
\hline NASDAQ & Equal to 1 if firm is listed on NASDAQ, 0 otherwise (CRSP) \\
\hline$B I G N$ & $\begin{array}{l}\text { Equal to } 1 \text { if firm is audited by Andersen, KPMG, PWC, Ernst \& Young, or Deloitte, and } \\
0 \text { otherwise }\end{array}$ \\
\hline BUSSEG & Number of business segments reported (Compustat segments) \\
\hline$M \& A$ & $\begin{array}{l}\text { Equal to } 1 \text { if firm is involved in merger or acquisition (Compustat footnote AFTNT1), } \\
\text { and } 0 \text { otherwise }\end{array}$ \\
\hline RESTRUCT & $\begin{array}{l}\text { Equal to } 1 \text { if firm is involved in restructuring as indicated by nonzero values for } \\
\text { Compustat items RCP, RCA, RCEPS, or RCP, and } 0 \text { otherwise }\end{array}$ \\
\hline$\triangle A U D I T O R$ & Equal to 1 if firm has a change in auditor, 0 otherwise \\
\hline FILINGS_8 K & Number of $8-\mathrm{K}$ filings on EDGAR in the 365 days before the statutory due date \\
\hline AF2003 & Equal to 1 if firm is accelerated filer in fiscal year 2003, and 0 otherwise \\
\hline LAF2006 & Equal to 1 if firm is large accelerated filer in fiscal year 2006, and 0 otherwise \\
\hline BD2006 & $\begin{array}{l}\text { Equal to } 1 \text { if firm is under scrutiny for stock options backdating in fiscal year } 2006 \text { as } \\
\text { identified by The Wall Street Journal, and } 0 \text { otherwise }\end{array}$ \\
\hline IC200\# & $\begin{array}{l}\text { Equal to } 1 \text { if firm is accelerated filer complying with SOX Section } 404 \text { in year 200\#, } \\
\text { where } \#=\{4,5,6\} \text {, and } 0 \text { otherwise }\end{array}$ \\
\hline$M W I C$ & $\begin{array}{l}\text { Equal to } 1 \text { if firm is accelerated filer complying with SOX Section } 404 \text { and has an } \\
\text { auditor attested material weakness in internal controls, and } 0 \text { for effective internal } \\
\text { controls (Audit Analytics). In the multivariate analysis (Table 5), this variable is set to } \\
0 \text { for non-accelerated filers and firm-years ending before } 15 \text { November } 2004\end{array}$ \\
\hline CARNT & $\begin{array}{l}\text { Cumulative abnormal returns around Form } 12 \mathrm{~b}-25 \text { filing summarized over days } 0 \text { and } \\
+1 \text {, computed as the difference between the raw (cum-dividends) daily return from } \\
\text { CRSP and the average daily return of similar sized firms as identified by the NYSE/ } \\
\text { AMEX/NASDAQ year-end cutoffs (CRSP file "erdport1") }\end{array}$ \\
\hline ICSOX & $\begin{array}{l}\text { Equal to } 1 \text { if firm provides an explanation for a filing delay in the Form } 12 \mathrm{~b}-25 \text { narrative } \\
\text { disclosure that is related to SOX internal control implementation or material weakness, } \\
0 \text { otherwise }\end{array}$ \\
\hline
\end{tabular}




\section{References}

Alford, A. W., Jones, J. J., \& Zmijewski, M. E. (1994). Extensions and violations of the statutory sec form 10-K filing requirements. Journal of Accounting and Economics, 17(1-2), 229-254.

Ashbaugh-Skaife, H., Collins, D. W., \& Kinney, W. R., Jr. (2007). The discovery and reporting of internal control deficiencies prior to sox-mandated audits. Journal of Accounting and Economics, 44(1-2), 166-192.

Ashbaugh-Skaife, H., Collins, D. W., Kinney, W. R., Jr., \& LaFond, R. (2008). The effect of SOX internal control deficiencies and their remediation on accrual quality. The Accounting Review, 83(1), 217-250.

Ashbaugh-Skaife, H., Collins, D. W., Kinney, W. R., Jr., \& LaFond, R. (2009). The effect of SOX internal control deficiencies on firm risk and cost of equity. Journal of Accounting Research, 47(1), $1-43$.

Asthana, S., \& Balsam, S. (2001). The effect of Edgar on the market reaction to 10-K filings. Journal of Accounting and Public Policy, 20(4-5), 349-372.

Bagnoli, M., Kross, W., \& Watts, S. G. (2002). The information in management's expected earnings report date: A day late, a penny short. Journal of Accounting Research, 40(5), 1275-1296.

Balsam, S., Bartov, E., \& Marquardt, C. (2002). Accruals management, investor sophistication, and equity valuation: Evidence from 10-Q filings. Journal of Accounting Research, 40(4), 987-1012.

Begley, J., \& Fischer, P. E. (1998). Is there information in an earnings announcement delay? Review of Accounting Studies, 3(4), 347-363.

Beneish, M. D., Billings, M. B., \& Hodder, L. D. (2008). Internal control weaknesses and information uncertainty. The Accounting Review, 83(3), 665-703.

Bryant-Kutcher, L., Peng, E. Y., \& Zvinakis, K. (2007). The impact of the accelerated filing deadline on timeliness of 10-K filings. Working paper, Colorado State University. http://papers.ssrn.com/ sol3/papers.cfm?abstract_id=735583.

Chambers, A. E., \& Penman, S. H. (1984). Timeliness of reporting and the stock price reaction to earnings announcements. Journal of Accounting Research, 22(1), 21-47.

DeFond, M. L., \& Francis, J. R. (2005). Audit research after Sarbanes-Oxley. Auditing: A Journal of Practice \& Theory, 24, 5-30.

Doyle, J., Ge, W., \& McVay, S. (2007a). Determinants of weaknesses in internal control over financial reporting. Journal of Accounting and Economics, 44(1-2), 193-223.

Doyle, J., Ge, W., \& McVay, S. (2007b). Accruals quality and internal control over financial reporting. The Accounting Review, 82(5), 1141-1170.

Durfee, D. (2004). Filing ever faster. CFO.com (April 1). http://www.cfo.com/printable/article.cfm/ 3012753/c_3046611.

Dutta, S., \& Trueman, B. (2002). The interpretation of information and corporate disclosure strategies. Review of Accounting Studies, 7(1), 75-96.

Dye, R. A. (1985). Disclosure of nonproprietary information. Journal of Accounting Research, 23(1), $123-145$.

Dye, R. A. (2001). An evaluation of "essays on disclosure" and the disclosure literature in accounting. Journal of Accounting and Economics, 32(1-3), 181-235.

Easton, P. D., \& Zmijewski, M. E. (1993). SEC form $10 \mathrm{~K} / 10 \mathrm{Q}$ reports and annual reports to shareholders: Reporting lags and squared market model prediction errors. Journal of Accounting Research, 31(1), 113-129.

Engel, E., Hayes, R. M., \& Wang, X. (2007). The Sarbanes-Oxley act and firms' going-private decisions. Journal of Accounting and Economics, 44(1-2), 116-145.

Ettredge, M. L., Sun, L., \& Li, C. (2006). The impact of SOX section 404 internal control quality assessment on audit delay in the SOX era. Auditing: A Journal of Practice \& Theory, 25(2), 1-23.

Feldman, R., Rosenfeld, B., Lazar, R., Livnat, J., \& Segal, B. (2006). Computerized retrieval and classification: An application to reasons for late filings with the Securities and Exchange Commission. Intelligent Data Analysis, 10(2), 183-195.

Gao, F., Wu, J. S., \& Zimmerman, J. L. (2009). Unintended consequences of granting small firms exemptions from securities regulation: Evidence from the Sarbanes-Oxley Act. Journal of Accounting Research, 47(2), 459-506.

Ge, W., \& McVay, S. (2005). The disclosure of material weaknesses in internal control after the Sarbanes-Oxley act. Accounting Horizons, 19(3), 137-158. 
Graybow, M. (2007). More big companies struggle to finish sec filings. Reuters.com (March 15). http://uk.reuters.com/article/2007/03/15/businesspro-sec-latefilers-dc-idUKN1539857920070315.

Griffin, P. A. (2003). Got information? Investor response to form 10-K and form 10-Q EDGAR filings. Review of Accounting Studies, 8(4), 433-460.

Grossman, S. J. (1981). The informational role of warranties and private disclosure about product quality. Journal of Law and Economics, 24(3), 461-483.

Grossman, S. J., \& Hart, O. D. (1980). Disclosure laws and takeover bids. The Journal of Finance, 35(2), 323-334.

Hammersley, J., Myers, L., \& Shakespeare, C. (2008). Market reactions to the disclosure of internal control weaknesses and to the characteristics of those weaknesses under section 302 of the Sarbanes Oxley act of 2002. Review of Accounting Studies, 13(1), 141-165.

Hansen, B., Pownall, G., \& Wang, X. (2009). The robustness of the Sarbanes Oxley effect on the US capital market. Review of Accounting Studies, 14(2), 401-439.

Hogan, C. E., \& Wilkins, M. S. (2008). Evidence on the audit risk model: Do auditors increase audit fees in the presence of internal control deficiencies? Contemporary Accounting Research, 25(1), 219-242.

Huddart, S. J., Ke, B., \& Shi, C. (2007). Jeopardy, non-public information, and insider trading around SEC 10-K and 10-Q filings. Journal of Accounting and Economics, 43(1), 3-36.

Jain, P. K., \& Rezaee, Z. (2006). The Sarbanes-Oxley Act of 2002 and capital-market behavior: Early evidence. Contemporary Accounting Research, 23(3), 629-654.

Kothari, S. P., Shu, S., \& Wysocki, P. D. (2009). Do managers withhold bad news? Journal of Accounting Research, 47(1), 241-276.

KPMG. (2003). Readiness for SEC timely filing requirements. KPMG defining issues 03-17.

Krishnan, J., \& Yang, J. S. (2009). Recent trends in audit report and earnings announcement lags. Accounting Horizons, 23(3), 265.

Kross, W., \& Schroeder, D. A. (1984). An empirical investigation of the effect of quarterly earnings announcement timing on stock returns. Journal of Accounting Research, 22(1), 153-176.

Lerman, A., \& Livnat, J. (2010). The new form 8-K disclosures. Review of Accounting Studies, 15(4), $752-778$.

Leuz, C., Triantis, A., \& Wang, Y. T. (2008). Why do firms go dark? Causes and economic consequences of voluntary SEC deregistrations. Journal of Accounting and Economics, 45(2-3), 181-208.

Milgrom, P. R. (1981). Good news and bad news: Representation theorems and applications. The Bell Journal of Economics, 12(2), 380-391.

Ogneva, M., Subramanyam, K. R., \& Raghunandan, K. (2007). Internal control weakness and cost of equity: Evidence from SOX section 404 disclosures. The Accounting Review, 82(5), 1255-1297.

Petersen, M. A. (2009). Estimating standard errors in finance panel data sets: Comparing approaches. Review of Financial Studies, 22(1), 435-480.

Qi, D., Wu, W., \& Haw, I. (2000). The incremental information content of SEC 10-K reports filed under the EDGAR system. Journal of Accounting, Auditing \& Finance, 15(1), 25-46.

Schwartz, K. B., \& Soo, B. S. (1996a). The association between auditor changes and reporting lags. Contemporary Accounting Research, 13(1), 353-370.

Schwartz, K. B., \& Soo, B. S. (1996b). Evidence of regulatory noncompliance with SEC disclosure rules on auditor changes. The Accounting Review, 71(4), 555-572.

Securities and Exchange Commission (SEC). (2002a). Final rule: Acceleration of periodic report filing dates and disclosure concerning website access to reports; Rel. No. 33-8128. http://www.sec.gov/ rules/final/33-8128.htm.

Securities and Exchange Commission (SEC). (2002b). Proposed rule: Acceleration of periodic report filing dates and disclosure concerning website access to reports; Rel. No. 33-8089. http://www. sec.gov/rules/proposed/33-8089.htm.

Securities and Exchange Commission (SEC). (2002c). Comments of Charles Schwab \& Co., Inc. on S709-02. http://www.sec.gov/rules/proposed/s70902/whcallcott1.htm.

Securities and Exchange Commission (SEC). (2003). Summary of comments relating to proposed amendments to accelerate periodic report filing dates and disclosure concerning website access to reports. http://www.sec.gov/rules/extra/33-8089summary.htm.

Securities and Exchange Commission (SEC). (2005a). Revisions to accelerated filer definition and accelerated deadlines for filing periodic reports. http://www.sec.gov/rules/final/33-8644.pdf.

Securities and Exchange Commission (SEC). (2005b). Self-regulatory organizations; New York Stock Exchange, Inc.; Order approving proposed rule change and amendment no. 3 thereto relating to 
procedures for companies that fail to file annual reports in a timely manner. http://www.sec. gov/rules/sro/nyse/34-51777.pdf.

Stice, E. K. (1991). The market reaction to 10-K and 10-Q filings and to subsequent the wall street journal earnings announcements. The Accounting Review, 66(1), 42.

Taub, S., \& Cook, D. (2007). Not all filers are accelerated equal. CFO.com (March 16). http://www. cfo.com/article.cfm/8872303?f=alerts.

Verrecchia, R. E. (1983). Discretionary disclosure. Journal of Accounting and Economics, 5, 179-194.

Wagenhofer, A. (1990). Voluntary disclosure with a strategic opponent. Journal of Accounting and Economics, 12(4), 341-363.

Wall Street Journal. (2007). Perfect payday—options scorecard. http://online.wsj.com/public/resources/ documents/info-optionsscore06-full.html.

You, H., \& Zhang, X. (2009). Financial reporting complexity and investor underreaction to 10-K information. Review of Accounting Studies, 14(4), 559-586.

Zhang, I. X. (2007). Economic consequences of the Sarbanes-Oxley act of 2002. Journal of Accounting and Economics, 44(1-2), 74-115. 